\title{
PENGARUH KONSELING KELOMPOK DENGAN MENGGUNAKAN TEKNIK MENULIS JURNAL UNTUK MENGURANGI PERILAKU BULLYING
}

\author{
Anis Mahfiroh ${ }^{1}$ \\ Dra. Indira Chanum, M.Psi ${ }^{2}$ \\ Dr. Dede Rahmat Hidayat, M.Psi ${ }^{3}$
}

\begin{abstract}
Abstrak
Penelitian ini dilakukan di SMA Negeri 53 Jakarta pada bulan November 2014. Penelitian eksperimen ini bertujuan untuk mengetahui pengaruh konseling kelompok dengan menggunakan teknik menulis jurnal untuk mengurangi perilaku bullying pada siswa kelas XI IPS SMA Negeri 53 Jakarta. Pengambilan sampel dipilih menggunakan teknik sampling purposive, sehingga sampel dalam penelitian ini adalah sepuluh orang siswa untuk menjadi kelompok eksperimen dan sepuluh orang siswa untuk menjadi kelompok kontrol yang merupakan siswa yang memiliki perilaku bullying dengan kategori sangat tinggi dan tinggi. Metode penelitian adalah Kuantitatif, dengan desain penelitian quasi experimental (nonequivalent control group design). Pengumpulan data dikumpulkan dengan menggunakan instrumen perilaku bullying. Teknik analisis data yang digunakan dalam menguji hipotesis pada penelitian ini adalah Mann Whitney U-Test untuk membandingkan hasil pre-test dan post-test. Hasil pengujian hipotesis menunjukkan bahwa nilai Asymp. Sig sebesar 0.000, yang berarti lebih kecil dari nilai signifikansi a 0.05. Dapat disimpulkan bahwa HO ditolak dan H1 diterima. Dapat ditarik kesimpulan teknik menulis jurnal berpengaruh dalam mengurangi perilaku bullying siswa kelas XI IPS di SMA Negeri 53 Jakarta.
\end{abstract}

Kata kunci: teknik menulis jurnal, konseling kelompok, bullying

\section{Pendahuluan}

Masa remaja merupakan masa transisi dari periode masa kanak-kanak menuju kedewasaan, masa dimana seseorang yang berangkat untuk mencari jati diri menjadi seseorang yang dewasa. Masa ini juga amat berisiko, sebagian anak remaja kesulitan menangani begitu banyak perubahan yang terjadi dalam suatu waktu. Dalam prosesnya, ba-nyak faktor yang dapat mempengaruhi perkembangan remaja seperti faktor pola asuh keluarga, lingkungan rumah, lingkungan sekolah, dll. Lingkung-an pergaulan dapat dikatakan sangat mempengaruhi perilaku remaja, seperti kekerasan yang sering terjadi dikalangan remaja baik secara fisik, verbal maupun nonverbal. Kekerasan ini dapat dikatakan sebagai perilaku bullying.

Bullying adalah tindakan menyerang yang dilakukan secara sadar dan sengaja dan atau di manipulasi oleh satu atau lebih banyak orang terhadap orang lain atau banyak, bullying dapat bertahan untuk waktu yang singkat atau bahkan selama bertahun-ta-

1 Mahasiswa Jurusan Bimbingan dan Konseling FIP UNJ, anis.mahfiroh@gmail.com

2 Dosen Bimbingan dan Konseling FIP UNJ, indirasunito@yahoo.com

3 Dosen Bimbingan dan Konseling FIP UNJ, d_r_hidayat@yahoo.com 
hun, dan ini adalah sebuah penyalahgunaan kekuasaan oleh mereka yang melakukannya (Sullivan, 2000). Kadang-kadang direncanakan, dan kadangkadang dilakukan dengan oportunis, kadang-kadang direncanakan terutama terhadap satu korban, dan kadang-kadang terjadi berturutan dan acak. Sedangkan perilaku bullying yang ada di sekolah tingkat SMA yang peneliti teliti, terlihat perilaku bullying berupa verbal seperti ejekan saat di dalam kelas, senioritas dalam satu sekolah, dan cyberbullying. Inilah yang membuat peran seorang guru Bimbingan dan Konseling (BK) sangat diperlukan. Guru BK di sekolah harus memberikan layanan menangani kasus yang terjadi di sekolah, khususnya yang berkaitan dengan bullying. Dalam hai ini peneliti menggunakan teknik Menulis Jurnal untuk mengurangi perilaku bullying pada siswa yang memiliki kriteria pelaku bullying. Teknik menulis jurnal dalam konseling kelompok di sekolah, siswa dituntut menulis tentang dirinya. Cara ini merupakan tindakan efektif untuk mengeksplorasi dan membawa kejelasan dan untuk membantu pengembangan pribadi.

Banyaknya kasus bullying serta dampak negatifnya terhadap perilaku remaja melatarbelakangi peneliti untuk melakukan sebuah penelitian guna menilai pengaruh teknik menulis jurnal yang dapat digunakan untuk membantu remaja mengurangi perilaku bullying mereka. Karena jika tidak segera ditangani, hal ini akan berdampak negatife untuk perkembangan remaja saat beranjak dewasa, khususnya dalam hal pendidikan lanjut dan karir, Jika tidak ditangani, mereka akan kesulitan dalam bergabung dengan lingkungannya di luar sana. Pembatasan masalah dalam penelitian ini adalah: Adakah Pengaruh Konseling Kelompok dengan Teknik Menulis Jurnal Untuk Mengurangi Perilaku Bullying Pada Siswa Kelas XI IPS SMA Negeri 53 Jakarta dan tujuan yang ingin dicapai dalam penelitian ini adalah untuk mengetahui pengaruh konseling kelompok dengan menggunakan teknik menulis jurnal untuk mengurangi perilaku bullying pada siswa kelas XI IPS SMA negeri 53 Jakarta.

\section{Perilaku Bullying}

Bullying merupakan tindakan agresif yang dilakukan untuk menyakiti orang lain secara fisik atau secara verbal atau secara psikologi yang dilakukan secara sadar. Bullying terjadi karena adanya ketidak seimbangan kekuatan antara korban dan pelaku, dan biasanya bullying dilakukan berulang kali. Ada tiga komponen penting dalam definisi ini: (a) Pertama, bullying adalah tindakan yang disengaja. Anak yang pengganggu ingin menyakiti korban, itu adalah bukan sebuah kebetulan. (b) Kedua, bullying ditandai dengan kejadian berulang. Bullying umumnya tidak dianggap sebagai tindakan acak atau sebuah insiden. Sebaliknya, seorang anak berulang kali dipilih oleh anak lain atau target dari seluruh kelompok anak-anak. Ini adalah sifat berulang bullying yang menyebabkan kecemasan dan ketakutan pada korban, sehingga antisipasi bullying menjadi bermasalah seperti bullying itu sendiri. (c) Ketiga, yang sangat penting, bullying ditandai dengan diferensial kekuasaan. Bullying adalah perjuangan yang tidak adil di mana anak yang memiliki beberapa keunggulan pengganggu atau kekuasaan atas anak yang menjadi korban (Dan Olweus, 2009).

Bentuk perilaku bullying: Perilaku bullying yang merupakan bentuk tindakan agresif yang membuat orang lain merasa tidak nyaman dan terluka baik secara fisik atau verbal atau secara psikologi. Beberapa bentuknya adalah 1) Fisik: menggigit memukul, menendang, dll. 2) Non-fisik: a) verbal: panggilan telepon yang kasar, memeras uang, menggunakan bahasa bernada seksual atau kasar, dll. b) non-verbal: Terbagi menjadi langsung (sering menyertai bullying fisik atau verbal dan termasuk ekspresi wajah dan gerakan yang kasar) dan tidak langsung, diantaranya memanipulasi dan merusak persahabatan secara sengaja, tidak mengikut sertakan, mengabaikan dan mengisolasi seseorang. 3) Cyberbullying : penghinaan dalam forum online, pesan gangguan, pelecehan, peniruan (impersonation), tipu muslihat, pengucilan secara sosial. 4) Psikologis: memandang sinis, memandang penuh ancaman, mempermalukan di depan umum, mencibir, dan lain sebgainya.

\section{Konseling Kelompok}

Konseling kelompok merupakan proses pemberian bantuan kepada siswa yang membutuhkan dengan memanfaatkan dinamika kelompok untuk mencapai tujuan-tujuan dalam bimbingan dan konseling. Konseling kelompok memungkinkan konselor bekerja dengan beberapa orang sekaligus 
sehingga dapat menghemat waktu dalam melaksanakan konseling.

Tahapan dalam konseling kelompok (Corey, 2012) adalah: 1) Tahap pra-konseling: Tahap ini adalah tahap persiapan atau perencanaan sebelum konseling. Supaya mendapatkan hasil yang maksimal, pembentukan kelompok harus direncanakan dengan baik. 2) Tahap orientasi dan eksplorasi: melakukan orientasi dan eksplorasi seperti menentukan struktur kelompok, memperkenalkan anggota kelompok, dan mengeksplorasi anggota kelompok. 3) Tahap Transisi: Pada tahap ini sering terjadi terjadi kecemasan, resistensi, konflik dan bahkan ambivalensi tentang keanggotaan mereka dalam kelompok, atau enggan jika harus membuka diri. Tugas pemimpin kelompok adalah mempersiapkan mereka bekerja untuk dapat merasa memiliki kelompoknya. 4) Tahap kegiatan: Kegiatan inti dari tahap ini adalah eksplorasi dan diskusi mengenai masalah anggota kelompok, dan membuat program tindakan yang nantinya akan dilaksanakan anggota kelompok untuk melakukan perubahan pada dirinya. 5) Tahap Konsolidasi: Pada tahap ini adalah waktunya untuk menyimpulkan, mengintegrasikan, dan menginterpretasi pengalaman yang telah kelompok dapatkan selama sesi konseling. 6) Tahap evaluasi dan tindak lanjut: Pada bagian evaluasi, pemimpin kelompok mengevaluasi seluruh kegiatan konseling kelompok dari awal dilaksanakannya pertemuan hingga akhir, kebermanfaatan kelompok, pengaruh kelompok bagi kehidupan anggota, serta kemajuankemajuan yang mereka alami setelah melaksanakan sesi konseling kelompok.

\section{Teknik Menulis Jurnal}

Menulis jurnal membantu anak untuk mengekspresikan emosi yang rumit yang berakhir pada perilaku bullying. Melalui teknik ini, siswa akan menuangkan cerita dan pengalamannya dalam sebuah narasi (narrative) yang dibuat seperti peristiwa-peristiwa yang pernah siswa alami. Narrative adalah tentang pilihan untuk bercerita dan menceritakan kembali dari kisah yang di sukai, unik, kontradiktif, kontingen, dan hal-hal yang menyimpang dalam kehidupan mereka. Pada teknik menulis jurnal selanjutnya, siswa diminta untuk menceritakan apa yang sudah mereka tuliskan didalam jurnal mereka (storytelling). Penggunaan storytelling itu sendiri, baik dalam terapi individu maupun kelompok, storytelling dapat meningkatkan ingatan pada saat peristiwa yang mungkin sulit untuk di urutkan dan berarti storytelling dapat menjadi media yang mendalam untuk memfasilitasi siswa dalam pengungkapan dan mengubahan pandangan tentang pribadinya.

Manfaat dari menulis jurnal adalah: 1) Menawarkan peluang baru untuk merenungkan perilaku bullying yang terjadi dalam diri mereka. 2) Mengkonfirmasi kepercayaan dalam versi dan pengalaman kegiatan sosial. 3) Memfasilitasi penyembuhan kerugian dari perilaku bullying yang telah dilakukan. 4) Membangun cara baru menafsirkan, memahami, dan menanggapi perilaku bullying di masa depan. 5) Menanamkan kesadaran diri yang memperkuat kepercayaan dalam perspektif sendiri. 6) Mendorong ketahanan untuk menavigasi tantangan sosial berhasil dan menjauh dari hubungan beracun seperti perilaku bullying. 7) Membangkitan motivasi anak untuk tidak terlibat dalam perilaku bullying.

\section{Metode Penelitian}

Subjek dalam penelitian ini adalah siswa - siswi kelas XI IPS SMA Negeri 53 Jakarta yaitu sebanyak 139 siswa. Sampel dalam penelitian ini adalah siswa - siswi yang memiliki karakteristik perilaku bully. Penelitian ini dilaksanakan dari bulan April dan selesai pada bulan November 2014. Tempat penelitian dilaksanakan di SMA Negeri 53 Jakarta pada tahun ajaran 2014/2015. Sekolah ini terletak di Jl. Cipinang Jaya II B, Jatinegara, Jakarta Timur. Adapun prosedur dalam pelaksanaan penelitian, dapat dilihat pada Tabel 1.

Teknik pengumpulan data yang digunakan pada penelitian ini adalah melalui penyebaran kuesioner tertutup model skala Likert. Instrumen utama dalam penelitian ini adalah kuesioner tertutup. Variabel pada penelitian ini adalah perilaku bullying. Dalam penelitian ini teknik analisis data dilakukan dengan menggunakan teknik Uji Mann-Whitney U-Test. Dalam penelitian ini, teknik analisis data dilakukan dengan menggunakan bantuan aplikasi Statistical Product and Service Solution (SPSS) versi 20.0 for windows. 
Tabel 1

Prosedur Pelaksanaan Penelitian

\begin{tabular}{|c|c|}
\hline Kegiatan & Urutan Kegiatan \\
\hline $\begin{array}{c}\text { Studi } \\
\text { Pendahuluan }\end{array}$ & $\begin{array}{l}\text { Peneliti melakukan wawancara kepada guru BK dan wakil } \\
\text { kepala sekolah bidang kesiswaan, dan guru kelas di SMA N } \\
53 \text { Jakarta mengenai perilaku bullying yang sering terjadi di } \\
\text { sekolah. Didapatkan hasil bahwa bullying yang sering } \\
\text { terjadi di dalam kelas maupun di duar kelas lebih banyak } \\
\text { dilakukan oleh siswa kelas XI jurusan IPS. }\end{array}$ \\
\hline Pre-test & $\begin{array}{l}\text { Peneliti memberikan lembar instrument mengenai perilaku } \\
\text { bullying kepada seluruh siswa kelas XI IPS sebanyak } 139 \\
\text { siswa. Kemudian peneliti sortir kembali sumber data yang } \\
\text { sesuai dengan keriteria samel penelitian yaitu siswa yang } \\
\text { memiliki perilaku bullying tinggi. Dari } 139 \text { anak terdapat } 20 \\
\text { anak yang memiliki perilaku bullying tinggi. }\end{array}$ \\
\hline $\begin{array}{c}\text { Sesi } 1 \\
\text { (Tahap } \\
\text { Pembentukan) }\end{array}$ & $\begin{array}{l}\text { 1. Peserta didik mengenalkan diri satu sama lain } \\
\text { 2. Peserta didik memperoleh penjelasan mengenai tujuan } \\
\text { diadakannya kegiatan konseling kelompok } \\
\text { 3. Peserta didik membuat lembar persetujuan mengikuti } \\
\text { kegiatan } \\
\text { 4. Peserta didik membuat kesepakatan mengenai } \\
\text { peraturan selama mengikuti kegiatan } \\
\text { 5. Penelitian dan peserta didik membuat kesepakatan } \\
\text { mengenai tempat, durasi waktu, dan jadwal pertemuan }\end{array}$ \\
\hline $\begin{array}{l}\text { Sesi } 2 \\
\text { (Tahap } \\
\text { Penggambaran } \\
\text { Diri) }\end{array}$ & $\begin{array}{l}\text { 1. Peneliti dan peserta bersama-sama me-review kegiatan } \\
\text { di pertemuan sebelumnya } \\
\text { 2. Peneliti mengajak peserta untuk melakukan ice-breaking } \\
\text { (ayo ke bulan) } \\
\text { 3. Peserta diberikan kertas kosong } \\
\text { 4. Peneliti meminta pesera untuk menggambarkan dirinya } \\
\text { dengan sebuah perumpamaan benda } \\
\text { 5. Masing-masing peserta menjelaskan tentang gambar } \\
\text { yang mereka buat di depan kelompok }\end{array}$ \\
\hline $\begin{array}{l}\text { Sesi } 3 \\
\text { (Tahapan } \\
\text { Penggambaran } \\
\text { Diri) }\end{array}$ & $\begin{array}{l}\text { 1. Peneliti dan peserta bersama-sama me-review kegiatan } \\
\text { di pertemuan sebelumnya } \\
\text { 2. Peneliti Peneliti memberikan sebuah puzzle yang } \\
\text { bergambarkan contoh dari perilaku bullying } \\
\text { 3. Peserta diminta untuk bersama merapikan puzzle } \\
\text { tersebut dengan waktu yang sudah ditentukan } \\
\text { 4. Masing-masing peserta mengambil kesimpulan tentang } \\
\text { gambar yang sudah tersusun dan tentang pertemuan } \\
\text { kali ini }\end{array}$ \\
\hline $\begin{array}{l}\text { Sesi } 4 \\
\text { (Tahapan } \\
\text { Menulis } \\
\text { Jurnal) }\end{array}$ & $\begin{array}{l}\text { 1. Peneliti dan peserta bersama-sama me-review kegiatan } \\
\text { di pertemuan sebelumnya } \\
\text { 2. mengajak peserta untuk melakukan ice-breaking (cerita } \\
\text { A-B-C...Z) } \\
\text { 3. Peneliti memberi tahu langkah-langkah menulis jurnal } \\
\text { dan apa saja yang diungkapkan dalam jurnal tentang } \\
\text { mereka } \\
\text { 4. Peserta memulai menulis jurnal masing-masing }\end{array}$ \\
\hline $\begin{array}{l}\text { Sesi } 5 \text { \& } 6 \\
\text { (Tahapan } \\
\text { Menulis } \\
\text { Jurnal) }\end{array}$ & $\begin{array}{l}\text { 1. Peneliti dan peserta bersama-sama me-review kegiatan } \\
\text { di pertemuan sebelumnya } \\
\text { 2. Peneliti mengajak peserta untuk melakukan ice-breaking } \\
\text { (angka motifasi) } \\
\text { 3. Masing-masing peserta menceritakan jurnal mereka di } \\
\text { depan kelompok } \\
\text { 4. Peserta diminta untuk memberikan pendapat disetiap } \\
\text { temen kelompoknya selesai menceritakan tentang } \\
\text { jurnalnya }\end{array}$ \\
\hline $\begin{array}{c}\text { Sesi } 7 \\
\text { (Tahapan } \\
\text { Refleksi Diri) }\end{array}$ & $\begin{array}{l}\text { 1. Peneliti dan peserta bersama-sama me-review kegiatan } \\
\text { di pertemuan sebelumnya } \\
\text { 2. Peneliti mengajak peserta untuk melakukan ice-breaking } \\
\text { (kisah si tupai) } \\
\text { 3. Masing-masing peserta diminta untuk mengambil } \\
\text { kesimpulan dari pertemuan selama konseling } \\
\text { berlangsung } \\
\text { 4. Peserta diminta untuk mengungkapkan perilaku bullying } \\
\text { apa saja yang pernah dilakukan dan menulisnya di dalam } \\
\text { jurnal mereka } \\
\text { 5. Dari perilaku yang sudah mereka tuliskan, peneliti } \\
\text { meminta peserta untuk mengarahkan perilaku tersebut }\end{array}$ \\
\hline $\begin{array}{c}\text { Sesi } 8 \\
\text { (Tahapan } \\
\text { Penutup) }\end{array}$ & $\begin{array}{l}\text { 1. Pserta didik mengungkapkan kesan-kesan selama } \\
\text { mengikuti kegiatan konseling } \\
\text { 2. Peserta menyampaikan harapan setelah selesai } \\
\text { mengikuti kegiatan konseling }\end{array}$ \\
\hline Post-test & $\begin{array}{l}\text { Peneliti memberikan lembar instrument mengenai perilaku } \\
\text { bullying kepada siswa yang telah melakukan konseling }\end{array}$ \\
\hline
\end{tabular}

\section{Hasil dan Pembahasan}

Pengujian hipotesis yang dilakukan dalam pene- litian ini adalah dengan menggunakan Mann Whitney-U Test dengan bantuan aplikasi SPSS versi 20.0, pada taraf kepercayaan 5\% atau Sig 0,05, diperoleh data nilai Asymp. Sig sebesar 0.000 yang berarti nilai probabilitas lebih kecil dari nilai signifikansi $\alpha$ 0.05. Dengan demikian dapat disimpulkan bahwa $\mathrm{H} 0$ ditolak dan $\mathrm{H} 1$ diterima, yaitu terjadi penurunan perilaku bullying siswa yang signifikan setelah diberikan perlakuan. Maka dapat disimpulkan bahwa terjadi peningkatan yang lebih besar pada kelompok eksperimen setelah diberikan teknik menulis jurnal. Oleh karena itu, kesimpulan dalam penelitian ini adalah teknik menulis jurnal memiliki pengaruh untuk mengurangi perilaku bullying pada siswa kelas XI IPS di SMA Negeri Jakarta.

Tabel 2

Data skor pre-test dan post-test perilaku bullying per

\begin{tabular}{|c|c|c|c|}
\hline Kelompok & $\begin{array}{c}\text { ketommolm } \\
\text { Pre-test }\end{array}$ & $\begin{array}{c}\text { Skor } \\
\text { Post-test }\end{array}$ & $\begin{array}{c}\text { Jumlah } \\
\text { Penurunan }\end{array}$ \\
\hline Kelompok Eksperimen & 94.9 & 70.7 & 24.2 \\
\hline Rata-rata & 94.9 & 70.7 & 24.2 \\
\hline Kelompok Kontrol & 85.3 & 78.9 & 6.4 \\
\hline Rata-rata & 85.3 & 78.9 & 6.4 \\
\hline
\end{tabular}

Berdasarkan data tersebut diketahui bahwa terdapat penurunan skor pre-test dan post-test pada masing-masing kelompok. Pada kelompok eksperimen rata-rata skor sebelum perlakuan sebesar 94.9, setelah diberikan perlakuan dengan menggunakan teknik menulis jurnal, skor rata-rata menjadi sebesar 70.7. Hal ini menunjukkan terjadi penurunan total skor rata-rata sebesar 24.2 poin dari kondisi awal sebelum diberikannya perlakuan terhadap responden. Sedangkan pada kelompok kontrol skor rata-rata sebelum perlakuan sebesar 85.3 dan setelah diberikan perlakuan dengan games, skor rata-rata menjadi sebesar 78.9. Terjadi penurunan skor rata-rata sebesar 6.4 poin. Hal ini menunjukkan bahwa terdapat penurunan skor rata-rata kelompok eksperimen lebih besar dari skor rata-rata kelompok kontrol. Penjelasan pencapaian siswa dalam kelompok eksperimen dapat dilihat sebagaimana digambarkan dalam table 3.

Berdasarkan hasil pre-test teknik menulis jurnal untuk menurunkan perilaku bullying, sebelum diberikannya teknik menulis jurnal, tingkat perilaku bullying siswa kelompok eksperimen berada pada kategori sangat tinggi dan tinggi. 
Tabel 3

Hasil pre-test dan post-test konseling kelompok dengan menggunakan teknik menulis jurnal untuk menurunkan perilaku bullying pada kelompok eksperimen

\begin{tabular}{|c|c|c|c|c|}
\hline $\begin{array}{c}\text { Nomor } \\
\text { Responden }\end{array}$ & $\begin{array}{c}\text { Skor Sebelum } \\
\text { Perlakuan }\end{array}$ & Kategorisasi & $\begin{array}{c}\text { Skor Setelah } \\
\text { Perlakuan }\end{array}$ & Kategorisasi \\
\hline 1 & 101 & Sangat Tinggi & 86 & Tinggi \\
\hline 7 & 107 & Sangat Tinggi & 70 & Sedang \\
\hline 51 & 95 & Sangat Tinggi & 70 & Sedang \\
\hline 124 & 96 & Sangat Tinggi & 71 & Sedang \\
\hline 131 & 94 & Tinggi & 63 & Rendah \\
\hline 59 & 90 & Tinggi & 57 & Rendah \\
\hline 72 & 94 & Tinggi & 72 & Sedang \\
\hline 37 & 90 & Tinggi & 73 & Sedang \\
\hline 98 & 90 & Tinggi & 73 & Sedang \\
\hline 74 & 92 & Tinggi & 72 & Tinggi \\
\hline Rata-rata & 94.9 & & 70.7 & \\
\hline
\end{tabular}

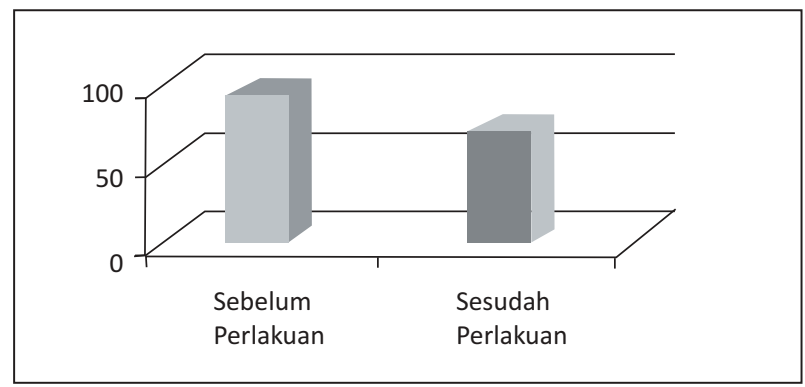

Grafik 1

Skor rata-rata hasil pre-test dan post-tes konseling kelompok dengan menggunakan teknik menulis jurnal untuk menurunkan perilaku bullying pada kelompok eksperimen

Rata-rata skor sebelum diberikan perlakuan adalah 94.9, setelah diberikan perlakuan berupa teknik menulis jurnal terjadi penurunan tingkat perilaku dengan rata-rata skor post-test sebesar 70.7. Ini berarti rata-rata skor penurunan setelah diberikan perilaku pada kelompok eksperimen sebesar 24.2 poin.

Hasil penelitian berdasarkan uji hipotesis menunjukkan bahwa adanya penurunan perilaku bullying siswa yang signifikan setelah diberikan perlakuan. Maka dapat disimpulkan bahwa terjadi penurunan yang lebih besar pada kelompok eksperimen setelah diberikan teknik menulis jurnal. Hal ini menjadikan hipotesis H0 ditolak dan H1 diterima. Sebelum diberikan perlakuan berupa konseling teknik menulis jurnal, skor dari 10 siswa berada pada kategori tinggi dan sangat tinggi. 4 orang siswa berada pada kategori sangat tinggi dan 6 orang siswa berada pada kategori tinggi. Setelah diberikan perlakuan berupa konseling dengan menggunakan teknik menulis jurnal, terlihat pada perubahan skor menjadi berada ditingkat tinggi, sedang, dan rendah. 2 orang siswa berada pada kategori tinggi, 6 orang siswa berada pada kategori sedang, dan 2 orang siswa berada pada kategori rendah. Peserta konseling kelompok beranggotakan dari 10 orang siswa yang memiliki tingkat perilaku bullying paling tinggi, terdiri dari 8 siswa laki-laki dan 2 siswa perempuan. Dari peserta laki-laki didapatkan informasi bahwa mereka lebih sering melakukan bullying dari aspek fisik seperti mendorong bahu lawan, memukul dibagian wajah, tidak jarang juga mereka melontarkan kata-kata kasar kepada lawan mereka. Lain halnya pada peserta perempuan, mereka mengaku bahwa mereka lebih sering melakukan bullying dari aspek verbal dan non-verbal seperti memaki lawannya dan menunjukkan ekspresi wajah tidak suka. Sering sekali mereka akui bahwa sekarang ini mereka sering melakukan cyberbullying kepada teman-teman mereka, seperti mengomentari dengan kalimat negatif tanpa member tahu nama mereka dan bertengkar via media sosial. Pada konseling ini, sebagian besar siswa mulai mampu memberikan respon yang baik dalam setiap tahapan konseling. Mereka mampu mengikuti dengan baik walau terkadang mengeluh dikarenakan mereka harus bersabar dalam menulis, bercerita, dan mendengarkan. Sebagian besar dari mereka mengakui bahwa perilaku bullying mereka disebabkan oleh keadaan keluarga khususnya orang tua dan lingkungan pergaulan teman sebaya.

\section{Kesimpulan dan Saran}

Berdasarkan hasil penelitian dan pembahasan diperoleh kesimpulan sebagai berikut:

1. Perilaku bullying siswa dapat dikurangi dengan menerapkan teknik menulis jurnal melalui tahapan penggambaran diri agar siswa dapat melihat dirinya dan menggambarkan tentang dirinya. Setelah itu bermain puzzle yang gunanya agar siswa dapat melatih kerjasama antar teman, melatih kesaba ran, dan mengatur emosi.

2. Pengurangan perilaku bullying siswa kelas XI IPS pada kelompok eksperimen yang diberikan perlakuan dengan teknik menulis jurnal lebih besar daripada rata-rata peningkatan pada kelompok kontrol. 
3. Berdasarkan hasil pengujian hipotesis dengan menggunakan teknik Mann Whitney-U Test Two Independent Sample, diperoleh hasil nilai asymp, Sig $=0,000$ Hipotesis penelitian diuji pada taraf signifikansi $\alpha=0.05$ atau dengan tingkat kesalahan sebesar 5\%, maka dapat disimpulkan bahwa $\mathrm{H} 0$ ditolak dan $\mathrm{H} 1$ diterima. Ini mengartikan bahwa terjadi penurunan perilaku bullying dengan menggunakan teknik menulis jurnal pada kelompok eksperimen.

Guru bimbingan konseling di sekolah disarankan menggunakan teknik menulis jurnal sebagai salah satu alternatif dalam menangani siswa yang bermasalah dengan perilaku bullying. Bagi peniti lainnya yang ingin mengembangkan penelitian mengenai konseling kelompok menggunakan teknik menulis jurnal untuk mengurangi perilaku bullying, sebaiknya memperkaya sumber bacaan dan referensi dan harus memperhatikan manajemen waktu dalam penelitian eksperimen harus diatur sebaik mungkin agar mendapatkan hasil penelitian yang maksimal.

\section{Daftar Pustaka}

Banks Ron, Bullying in Schools, 1997, ERIC Digest [Online]. Available: (http://npin.org/library/pre1998/ n00416/n00416.html), Diunduh tanggal 16 Januari 2014.

Cattanach Ann. Introduction to Play Therapy, (USA: Brunner-Routledge, 2003)

Gerald Corey, Theory \& Practice of Group Counseling: Eight Edition, Brooks/Cole, Belmont, 2012

Olweus. Dan, Bullying at School: what we know and what we can do, (USA: Blakwell 2004

Schaefer. C. E, Kaduson. H. G, Contemporary Play Therapy, (New York: The Guilford Press, 2006)

SEJIWA, Bullying: Mengatasi Kekerasan di Sekolah dan Lingkungan, (Jakarta: PT Grasindo, 2008)

Sugiyono, Metode Penelitian Pendidikan: Pendekatan Kuantitatif, Kualitatif, dan R\&D, (Bandung: CV. Alfabeta, 2010)

Sullivan Keith, The Anti-Bullying Handbook, (London: Oxford University Press, 2011) 